${ }^{1}$ M.P. Semenenko Institute of Geochemistry, Mineralogy and Ore Formation of the NAS of Ukraine, Kyiv, Ukraine

E-mail: regulgeo@gmail.com

${ }^{2}$ Curtin University, School of Earth and Planetary Sciences, Perth, Australia

E-mail: leonid.shumlyanskyy@curtin.edu.au, S.Wilde@curtin.edu.au

${ }^{3}$ Swedish Museum of Natural History, Stockholm, Sweden

E-mail: martin.whitehouse@nrm.se

${ }^{4}$ Department of Earth and Planetary Sciences, University of California, Riverside, CA 92521, USA

E-mail: andreyb@ucr.edu

*Corresponding author

\title{
THE U-Pb AGE AND Lu-Hf ISOTOPE SYSTEMATICS \\ OF ZIRCON FROM THE HULIAIPOLE METAVOLCANICS, THE AZOV DOMAIN OF THE UKRAINIAN SHIELD: EVIDENCE FOR THE PALEOARCHEAN-HADEAN CRUST
}

\begin{abstract}
The Azov Domain occurs as a part of a larger Mesoarchean (3.2-3.0 Ga) craton, fragments of which are preserved in the eastern part of the Ukrainian Shield and as a block of the Kursk Magnetic Anomaly (KMA). In the NeoarcheanPalaeoproterozoic time, it was fragmented into several tectonic blocks: Vovcha, Remivka, Huliaipole, Bilotserkivka, and Saltych. The northern part of the Huliaipole Block is composed of tonalite-trondhjemite-granodiorite (TTG) rock association, that hosts the Kosivtsevo greenstone structure. It is composed of metamorphosed rocks of the jaspilite-komatiite-tholeiite association (the Kosivtsevo unit), which corresponds to the Sura Suite of the Konka Series of the Middle Dnieper Domain. The Neoarchean-Paleoproterozoic formations are represented by volcano-sedimentary rocks of the Huliaipole Suite and granitoids of the Dobropillya and Anadol complexes. Granitoids of the Dobropillya complex host numerous pyroxenite, gneiss, and plagioclase granite xenoliths. The U-Pb zircon age of granitoids of the Dobropillya Complex is $2040 \mathrm{Ma}$ and inherited zircon has an age up to $3400 \mathrm{Ma}$. Small intrusions of two-feldspar granites of the Anadol Complex are widespread in the Ternuvate structure. Their U-Pb monazite age is $2190 \mathrm{Ma}$. In the central part of the Huliaipole Block, the NW-striking Huliaipole syncline $(3.5 \times 9 \mathrm{~km})$ occurs. This structure is composed of volcano-sedimentary rocks of the Huliaipole Suite, which unconformably overlie Archean TTG. Felsic and intermediate metavolcanics are confined mainly to ferruginous quartzites of the middle Subsuites. To a limited extent, meta-andesites and felsic metavolcanics are also found in the lower and upper Huliaipole Subsuites. Zircons from meta-andesites and felsic metavolcanics of the Huliaipole Suite are very heterogeneous, indicating their crustal derivation. The $U-P b$ age of zircon populations from metadacite of the Huliaipole Suite was determined using the LA-ICP-MS method at 3085-2850 and 3700-3360 Ma. In addition, the age of the two crystals exceeded $3800 \mathrm{Ma}$. According to geological and geochronological data, the Huliaipole Block, $30 \times 50 \mathrm{~km}$ in size, is composed of rocks and relicts of the Hadean, Archean, and Palaeoproterozoic eons. The oldest nucleoid of the Azov Domain
\end{abstract}

Citation: Artemenko G.V., Shumlyanskyy L.V., Wilde S.A., Whitehouse M.J., Bekker A.Yu., 2021. The U-Pb age and Lu-Hf isotope systematics of zircon from the Huliaipole metavolcanics, the Azov domain of the Ukrainian shield: evidence for the Paleoarchean-Hadean crust. Geological Journal (Ukraine). No. 1 (374), pp. 3-16. https://doi.org/10.30836/ igs.1025-6814.2021.1.2169899

Цит ування: Артеменко Г.В., Шумлянський Л.В., Wilde S.A., Whitehouse M.J., Bekker A.Yu. U-Pb вік та Lu-Hf ізотопна систематика циркону з метавулканітів Гуляйпільського блоку, Приазовський домен Українського щита: свідчення про палеоархей-гадейську кору. Геологічний журнал. 2021. № 1 (374). C. 3-16. https://doi. org/10.30836/igs.1025-6814.2021.1.2169899 
has probably been formed between 3.97 to $3.3 \mathrm{Ga}$. The unique peculiarity of this structure is that it has never experienced granulite stage of metamorphism. This allows consideration of the Huliaipole block as an example of the continental crust that has been formed in a plume geodynamic regime. During the Mesoarchean (3.2-3.0 Ga), it became a part of the Middle Dnieper-Azov-Kursk granite-greenstone terrane. Felsic and intermediate volcanics of the Huliaipole Suite could have formed due to melting of the sialic crust, including rocks of the Hadean and Archean age, as a result of underplating of basic melts during the formation of the Neoarchean to Paleoproterozoic rift structures.

Keywords: The West Azov; the Huliaipole block, Hadean; Archean; the Ukrainian Shield; the U-Pb age.

\section{Introduction}

In the Ukrainian Shield, rocks of the Earth's early crust were found in the Azov and Dniester-Bouh domains (Bibikova and Williams, 1990; Claesson et al., 2015, 2019; Shumlyanskyy et al., 2021). In the Dniester-Bouh Domain, they are highly metamorphosed and represented by enderbites and mafic schists reaching in age $3.8 \mathrm{Ga}$. A special feature of the Archean rocks in the Azov Domain is a relatively low metamorphic grade, not exceeding the epidote-amphibolite to amphibolite facies. Here, tonalites with ages of 3.67, 3.5, and 3.3 Ga have been identified (Bibikova and Williams, 1990; Artemenko et al., 2002, 2014; LobachZhuchenko et al., 2010). Metaterrigenous rocks in the Soroki greenstone structure (GS) and Neoarchean to Palaeoproterozoic troughs contain detrital zircon varying in age from 3.8 to $3.3 \mathrm{Ga}$ (Bibikova et al., 2010), which indicate the presence in the Azov Domain of ancient rocks yet undiscovered. Some researchers suggested that ancient granulite-gneissic complexes of the Azov and DniesterBouh domains, as well as of the Voronezh Crystalline Massif, represented fragments of one of the oldest protocratons (Nozhkin and Krestin, 1984). Claesson et al. (2015) suggested a model of the autonomous evolution of the "Early Archean cores" of the Azov and Dniester-Bouh domains, which has been supported by the recent geological data.

\section{Geological setting of the Azov Domain}

The Azov Domain occurs as a part of a larger Mesoarchean (3.2-3.0 Ga) craton, fragments of which are preserved in the eastern part of the Ukrainian Shield and as a block of the Kursk Magnetic Anomaly (KMA). In the Neoarchean-Palaeoproterozoic time, it was fragmented into several tectonic blocks: Vovcha, Remivka, Huliaipole,
Bilotserkivka, and Saltych. Size of the Huliaipole block is $30 \times 50 \mathrm{~km}$. To the west, north, and east, $\mathrm{t}$ is bordered by the Orekhiv-Pavlohrad structure, the Vovcha and Remivka blocks, respectively (Fig. 1). The Haichur fault of NW strike separates the Huliaipole and Remivka blocks; the Mesoarchean Kosivtsevo greenstone structure is confined to this fault. To the south, the Huliaipole Block is bordered by the Bilotserkivka Syncline and Korsak-Stulneve Anticline. Analyzing the geological position of greenstone belts in this area, which are characterized by a concentric shape and distinct confinement to the faults, (Berzenin, 1990) was the first to assume that they developed on the Paleoarchean granulite-gneissic basement above the mantle plume. The northern part of the Huliaipole Block comprises tonalite-trondhjemite-granodiorite (TTG) rock association, which hosts fragments of greenstone structures, while its central and southern parts are almost completely composed of younger granitoids. In the central part of the Huliaipole Block, the Huliaipole syncline $(3.5 \times 9 \mathrm{~km})$ of the NW strike occurs (Zhukov et al., 1978). Syncline limbs are plunging to the centre at an angle of 50-70 ${ }^{\circ}$ According to geophysical data, the fold extends down to the depth of 2.1-2.3 km. This structure is composed of a $1700 \mathrm{~m}$ thick volcanosedimentary sequence of the Huliaipole Suite, unconformably overlying Archean TTG. The Huliaipole Suite consists of three subsuites. The lower one (250 m thick) is composed of two-mica and andalusite-staurolite quartzites and schists; the middle one ( $450 \mathrm{~m}$ thick) consists of ferruginous quartzites and felsic to intermediate metavolcanics; the upper one ( $1000 \mathrm{~m}$ thick) is composed of biotite schists, often graphite-bearing, rarely high-Al quartzites and quartzite schists with flysch-like alternations. To a limited extent, meta-andesites and felsic metavolcanics reaching $70 \mathrm{~m}$ in thickness are also found in the lower and upper Huliaipole subsuites (Glevasskiy et al., 1985). A lateral replacement 


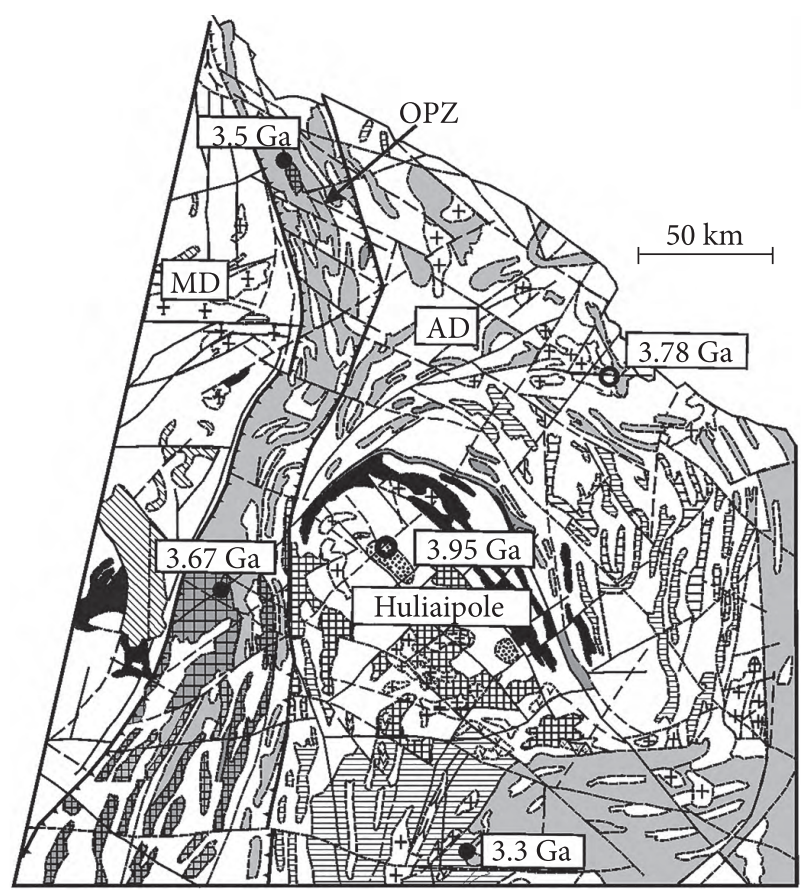

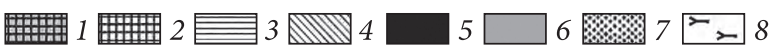

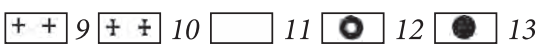

Fig. 1. Schematic geological map of the northern part of the West Azov area (Geological map..., 2014) with changes and additions). MD - the Middle-Dnieper Domain, OPZ - the Orekhiv-Pavlohrad Zone: 1 - the Novopavlivka unit, 2 - the Novopavlivka Complex, 3 - the West Azov Series, 4 - the Auly Series, 5 - greenstone belts, 6 - the Central-Azov Series, 7 - the Huliaipole Suite, 8 - alkaline intrusions, 9 - Paleoproterozoic K-Na granites, 10 - archean K-Na granites. 11 - plagioclase migmatites of the Shevchenko and Dnipro complexes, 12 - tonalite dating sites, 13 - dating sites of detrital and xenogenic zircons in felsic metavolcanics

of ferruginous quartzites by metavolcanics is observed from the margins towards the centre of the structure. In the same direction, in the lower and upper subsuites, clay-rich facies are replaced by sandy ones. The multi-grain detrital zircon fractions from quartzites of the Lower Huliaipole Subsuite yielded the U-Pb (TIMS) age of $2.9 \pm 0.1 \mathrm{Ga}$; the metamorphism of these rocks was dated at 2.14 Ga (Tatarinova et al., 2001).

\section{Analytical methods}

Zircon has been extracted from the rock using A shaking table, heavyliquids and magnetic separator to produce the heavy non-magnetic fraction. Zircons were hand-picked under a binocular microscope. Silicate rock analyses were carried out at the

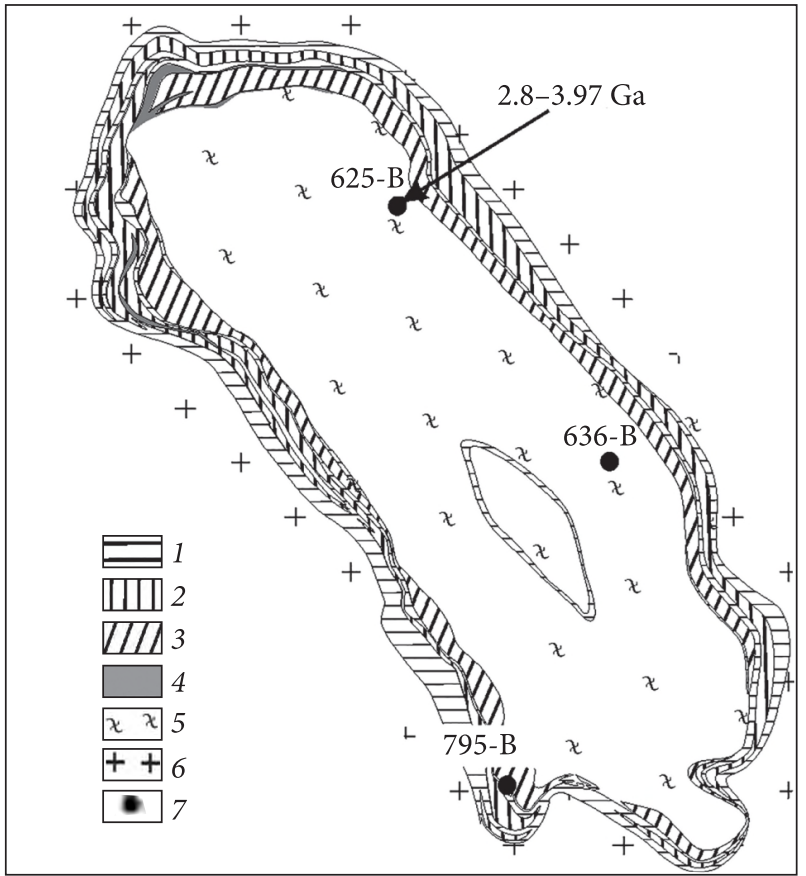

Fig. 2. A schematic geological map of the Huliaipole syncline (Glevassky et al., 1985): 1 - quartzites, metasandstones; 2 - andalusite-biotite-magnetite shales; 3 magnetite, silicate-magnetite quartzites; $4-$ magnetitesilicate quartzites; 5 - quartz-feldspar-biotite shales; 6 amphibole-biotite plagiogranites; 7 -drill-hole numbers

IGMOF of NAS of Ukraine, Kyiv. Concentrations of rare and trace elements in the rocks were determined using the ICP-MS method in the Institute of Microelectronics Technology and High-Purity Materials of the Russian Academy of Sciences (IMTM RAS), Chernogolovka, Russia. The validity of analyses was checked by the means of determination of international and Russian reference samples GSP-2, VM, SGD-1A, ST-1. Concentration measuring errors were 3 to $5 \mathrm{wt} \%$ for most elements.

Zircon morphology has been studied under an optical microscope, whereas the internal structure was documented using cathodoluminescence. $\mathrm{U}-\mathrm{Pb}$ zircon and monazite geochronology were performed at the University of California, Santa Barbara, using a Nu Plasma HR MC-ICPMS and a Photon Machines Excite 193 excimer ArF laser-ablation system equipped with a HeLex sample cell. Spots were ablated during a 15-second analysis, run at $4 \mathrm{~Hz}$ and $\sim 1 \mathrm{j} / \mathrm{cm}^{2}$, yielding a pit depth of $\sim 5 \mu \mathrm{m}$. Sample analyses were preceded by a 15 -second baseline measurement and unknown analyses were corrected with the 91500 reference material 


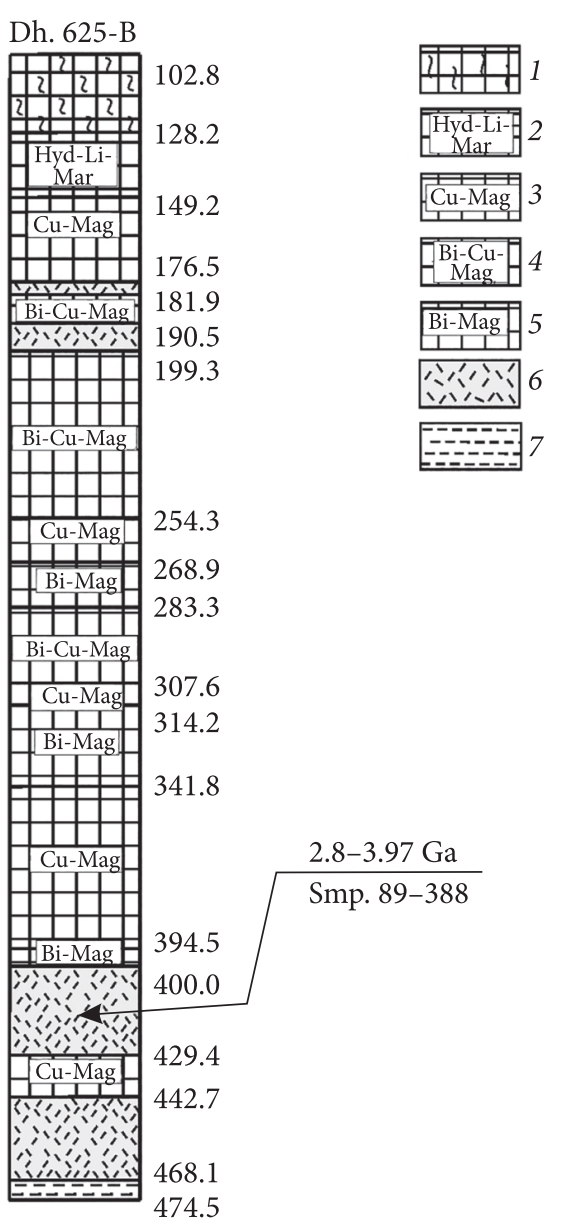

Fig. 3. A schematic log of the drill-hole 625-B: 1 - weathering crust of barren quartzites; 2 - quartzites with hydromica-limonite-martite (Hyd-Li-Mar, iron-rich weathering crust); 3 - quartzites with cummingtonite-magnetite (Cu-Mag); 4 - quartzites with biotite-cummingtonite-magnetite (Bi-Cu-Mag); 5 - quartzites with biotite-magnetite (Bi-Mag); 6 - metamorphosed felsic volcanics; 7 - biotite schist

(1062 Ma; Wiedenbeck et al., 1995) approximately every 10 analyses. For quality control, secondary RMs included GJ-1(602 Ma; Jackson et al., 2004; Kylander-Clark et al., 2013), and Plešovice (337 Ma; Sláma et al., 2008), and returned ages within $2 \%$ of the accepted ${ }^{206} \mathrm{~Pb} /{ }^{238} \mathrm{U}$ ages. All age errors reported are $2 \sigma$.

The Lu-Hf isotope composition was measured on a $\mathrm{Nu}$ Plasma II multi-collector inductively coupled plasma mass spectrometer in the John de Laeter Centre, Curtin University, Australia. All isotopes $\left({ }^{180} \mathrm{Hf},{ }^{179} \mathrm{Hf},{ }^{178} \mathrm{Hf},{ }^{177} \mathrm{Hf},{ }^{176} \mathrm{Hf},{ }^{175} \mathrm{Lu},{ }^{174} \mathrm{Hf}\right.$, ${ }^{173} \mathrm{Yb},{ }^{172} \mathrm{Yb}$ and ${ }^{171} \mathrm{Yb}$ ) were counted on the Faraday collector array. Contributions of ${ }^{176} \mathrm{Yb}$ and ${ }^{176} \mathrm{Lu}$ were removed from the 176-mass signal using
${ }^{176} \mathrm{Yb} /{ }^{173} \mathrm{Yb}=0.7962$ and ${ }^{176} \mathrm{Lu} /{ }^{175} \mathrm{Lu}=0.02655$ with an exponential-law mass bias correction assuming ${ }^{172} \mathrm{Yb} /{ }^{173} \mathrm{Yb}=1.35274$ (Chu et al., 2002). The interference-corrected ${ }^{176} \mathrm{Hf} /{ }^{177} \mathrm{Hf}$ was normalised to ${ }^{179} \mathrm{Hf} /{ }^{177} \mathrm{Hf}=0.7325$ (Patchett and Tatsumoto, 1980) for mass bias correction. Zircon crystals from the Mud Tank carbonatite were analysed together with the samples in each session to monitor the accuracy of the results. Zircons 91500; Plešovice; GJ- 1and R33 were also run as secondary reference standards. All reference material yielded ${ }^{176} \mathrm{Hf} /{ }^{177} \mathrm{Hf}$ ratios within an uncertainty of their respective reported values. Calculation of initial ${ }^{176} \mathrm{Hf} /{ }^{177} \mathrm{Hf}$ and $\varepsilon \mathrm{Hf}$ values for unknown zircons employed the measured ${ }^{207} \mathrm{~Pb} /{ }^{206} \mathrm{~Pb}$ spot date; a $\lambda^{176} \mathrm{Lu}$ decay constant of $1.867 \times 10^{-11}$ (Söderlund et al., 2004); and a present-day Chondritic Uniform Reservoir (CHUR) ${ }^{176} \mathrm{Hf} /{ }^{177} \mathrm{Hf}=0.282785$ and ${ }^{176} \mathrm{Lu} /{ }^{177} \mathrm{Hf}=0.0336$ (Bouvier et al., 2008).

\section{Results}

A possible presence of an ancient crust in the $\mathrm{Hu}-$ liaipole Block is supported by a large number of xenoliths in the granitoids of the Dobropillya Complex and the ubiquitous presence of xenocrystic zircons (Shcherbak et al., 2000). The Paleoarchean age of $3.3 \mathrm{Ga}$ of xenocrystic zircon (multiple zircon grain method) was determined by Shcherbak et al. (2000) and of 3.4 Ga (SHRIMP U-Pb method) by Stepanyuk et al. (2007). A large amount of xenocrystic zircon was also found in metamorphosed andesites and dacites of the Huliaipole Suite. These zircons were dated in this study applying the LA-ICP-MS method. For the most ancient zircons, the age was also confirmed by secondary ion mass spectrometry (SIMS).

\section{Petrography}

The sampled interval is composed of metadacites (sample 89-388, drill-hole 625-B, int. 424.4-429.4 meters) (Figs 2, 3). The texture of the rock is blastoporphyritic with a lepidogranoblastic groundmass (Fig. $4 a, b, c$ ). Phenocrysts are represented by albite. Phenocrysts are often granulated and transformed into an aggregate of fine grains. Secondary minerals in phenocrysts are biotite, sericite, muscovite, chlorite, carbonate, and magnetite. The groundmass is composed of (vol. \%): quartz + albite $-75-77$, biotite $-20-22$, apatite $-3-5$, 

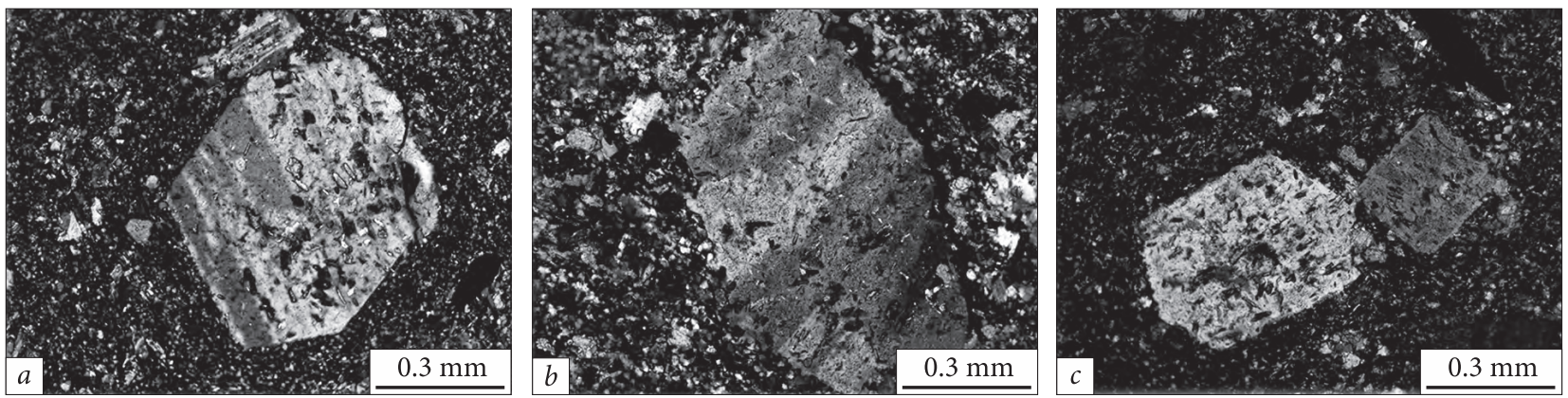

Fig. 4. Photomicrographs of thin sections of metadacites of the Huliaipole Suite, drill-hole 625-B: $a-$ sample 89-384, depth $424.8 \mathrm{~m}$; $b$ - sample 89-385, depth $427.4 \mathrm{~m}$; $c$ - sample 89-386, depth $428.6 \mathrm{~m}$. Images were taken using a polarizing microscope ECLIPSE LV100 POL. Crossed analyzers

Table 1. Chemical composition of metavolcanics of the Huliaipole Suite

\begin{tabular}{|l|c|c|c|c||l|c|c|c|c|}
\hline \multicolumn{1}{|c|}{$\%$} & $89-156$ & $89 / 463$ & $89 / 381$ & $89 / 388$ & $\%$ & $89-156$ & $89 / 463$ & $89 / 381$ & $89 / 388$ \\
\hline $\mathrm{SiO}_{2}$ & 60.70 & 62.58 & 63.98 & 65.70 & $\mathrm{~K}_{2} \mathrm{O}$ & 3.52 & 3.60 & 6.00 & 3.18 \\
$\mathrm{TiO}_{2}$ & 0.74 & 0.46 & 0.47 & 0.57 & $\mathrm{~S}_{\text {общ }}$ & 0.30 & 0.23 & 0.24 & 0.13 \\
$\mathrm{Al}_{2} \mathrm{O}_{3}$ & 14.60 & 13.74 & 13.36 & 13.93 & $\mathrm{P}_{2} \mathrm{O}_{5}$ & 0.36 & 0.24 & 0.10 & 0.24 \\
$\mathrm{Fe}_{2} \mathrm{O}_{3}$ & 0.35 & 0.72 & 0.65 & 1.41 & $\mathrm{CO}_{2}$ & 2.69 & 2.24 & 0.07 & 1.30 \\
$\mathrm{FeO}$ & 4.70 & 3.60 & 3.38 & 3.38 & $\mathrm{H}_{2} \mathrm{O}-$ & traces & 0.08 & 0.12 & traces \\
$\mathrm{MnO}$ & 0.08 & 0.06 & 0.05 & traces & LOI & 0.34 & 0.56 & 2.64 & 0.59 \\
$\mathrm{MgO}$ & 1.90 & 2.26 & 1.24 & 1.79 & Total & 99.68 & 99.67 & 99.58 & 99.62 \\
$\mathrm{CaO}$ & 5.10 & 3.96 & 3.50 & 3.62 & $\mathrm{Mg} \#$ & 40.3 & 48.7 & 35.8 & 40.7 \\
$\mathrm{Na}_{2} \mathrm{O}$ & 4.30 & 5.34 & 3.78 & 3.78 & & & & &
\end{tabular}

\begin{tabular}{|l|c|c|c|c||l|c|c|c|c|}
\hline Ppm & $89-156$ & $89 / 463$ & $89 / 381$ & $89 / 388$ & $\mathrm{Ppm}$ & $89-156$ & $89 / 463$ & $89 / 381$ & $89 / 388$ \\
\hline $\mathrm{Cs}$ & - & 18.53 & - & 4.8 & $\mathrm{La}$ & 32.50 & 29.05 & 35.9 & 38.3 \\
$\mathrm{Li}$ & - & 14.88 & - & 23 & $\mathrm{Ce}$ & 62 & 57.07 & 68.1 & 76.0 \\
$\mathrm{Be}$ & - & 1.94 & - & 1.4 & $\mathrm{Pr}$ & 7.07 & 6.36 & 7.60 & 7.9 \\
$\mathrm{Rb}$ & 97.10 & 96.90 & 102.6 & 174 & $\mathrm{Nd}$ & 26.60 & 24.87 & 26.7 & 29 \\
$\mathrm{Sr}$ & 816 & 742.9 & 812.1 & 647 & $\mathrm{Sm}$ & 4.75 & 4.15 & 4.52 & 4.5 \\
$\mathrm{Ba}$ & 1400 & 1953 & 2116 & 2327 & $\mathrm{Eu}$ & 1.70 & 1.26 & 1.23 & 1.1 \\
$\mathrm{~V}$ & 64.50 & 64.78 & 67 & 42.5 & $\mathrm{Gd}$ & 3.61 & 3.81 & 3.14 & 3.4 \\
$\mathrm{Cr}$ & 21.30 & 70.42 & - & 41.7 & $\mathrm{~Tb}$ & 0.49 & 0.39 & 0.36 & 0.41 \\
$\mathrm{Co}$ & 7.29 & 12.55 & 9.6 & 7.5 & $\mathrm{Dy}$ & 1.98 & 2.11 & 1.45 & 1.6 \\
$\mathrm{Ni}$ & 15 & 33.61 & 27.2 & 19.3 & $\mathrm{Ho}$ & 0.30 & 0.38 & 0.23 & 0.26 \\
$\mathrm{Cu}$ & - & 26.93 & 17.4 & 30.2 & $\mathrm{Er}$ & 0.73 & 1.09 & 0.60 & 0.66 \\
$\mathrm{Zn}$ & - & 70.31 & 60 & 58.2 & $\mathrm{Tm}$ & 0.092 & 0.14 & 0.08 & 0.088 \\
$\mathrm{Ga}$ & - & 47.55 & - & 16.6 & $\mathrm{Yb}$ & 0.51 & 0.95 & 0.53 & 0.54 \\
$\mathrm{As}$ & - & 2.13 & - & 0.48 & $\mathrm{Lu}$ & 0.072 & 0.14 & 0.06 & 0.08 \\
$\mathrm{Sc}$ & - & 18.53 & - & 4.1 & $\mathrm{Mo}$ & - & 0.83 & 0.2 & 0.49 \\
$\mathrm{Ge}$ & - & - & - & - & $\mathrm{Ag}$ & - & 70.43 & $<0.1$ & - \\
$\mathrm{Y}$ & 8.19 & 8.17 & 7.0 & 7.5 & $\mathrm{Ta}$ & 0.37 & - & 0.3 & 0.42 \\
$\mathrm{Nb}$ & 6.49 & 4.82 & 5.0 & 6.7 & $\mathrm{~Pb}$ & - & 17.70 & 9.5 & 19.2 \\
$\mathrm{Zr}$ & 160 & 116.4 & 162.6 & 190 & $\mathrm{~W}$ & - & 0.44 & - & 7.5 \\
$\mathrm{Hf}$ & - & 3.48 & 3.3 & 4.9 & $(\mathrm{La} / \mathrm{Yb})_{\mathrm{N}}$ & 45.7 & 21.9 & 48.6 & 50.9 \\
$\mathrm{U}$ & 1.41 & 1.83 & 1.4 & 1.4 & $\mathrm{Eu} / \mathrm{Eu}$ & 1.26 & 0.97 & 1.0 & 0.97 \\
$\mathrm{Th}$ & 6.71 & 7.25 & 5.6 & 6.5 & $\mathrm{Nb} / \mathrm{La}$ & 0.20 & 0.17 & 0.14 & 0.17 \\
$\mathrm{Sn}$ & - & 0.70 & - & 1.1 & $\mathrm{Nb} / \mathrm{Ce}$ & 0.11 & 0.08 & 0.07 & 0.09 \\
$\mathrm{Sb}$ & - & 0.12 & - & 0.25 & $\mathrm{Th} / \mathrm{Yb}$ & 13.2 & 7.4 & 10.6 & 12 \\
\hline
\end{tabular}

Note. 1 - meta-andesite, drill-hole 636-B, depth 384.5-384.7 m (sample 89-156); 2 - meta-andesite, drill-hole 795-B, depth 392-395.7 m (sample 89-463); 3 - meta-andesite, drill-hole 625-B, depth 424.4-429.4 m (sample 89-388); 4 - metadacite, drill-hole 625-B (sample 89-381). $\mathrm{Mg} \#$ is $\mathrm{Mg} /\left(\mathrm{Mg}+\mathrm{Fe}_{\text {total }}\right)$ in cation mole percent. 


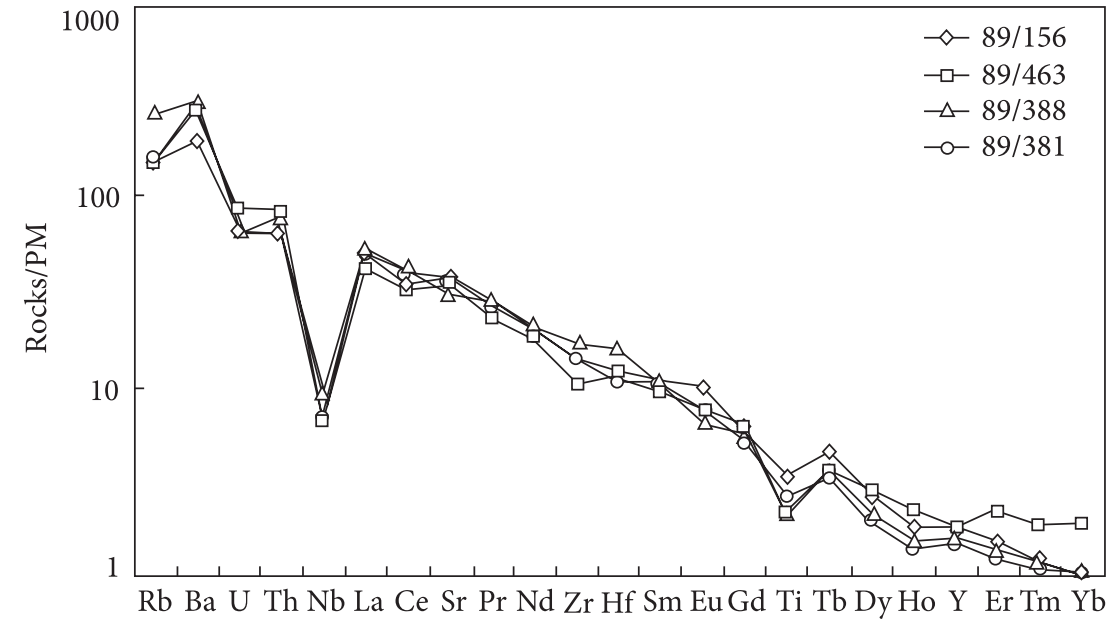

Fig. 5. Primitive mantle-normalized (Sun, McDonough, 1989) multi-element plot for meta-andesites and metadacites of the Huliaipole Suite
Fig. 6. Chondrite-normalized REE pattern for meta-andesites and metadacites of the Huliaipole Suite (Sun, McDonough, 1989)

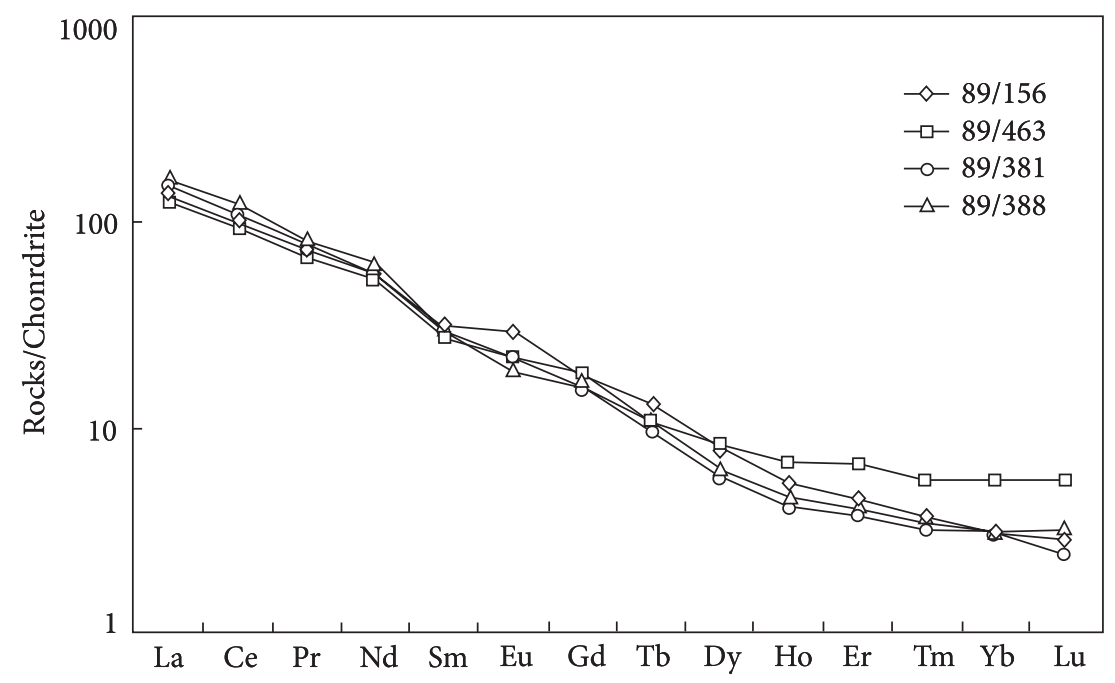

magnetite - up to 1 , chlorite and titanomorphite - fractions of \%, muscovite and zircon rare grains. Quartz and albite form aggregates of isometric grains having $0.02 \mathrm{~mm}$ in size. Biotite and chlorite are unevenly distributed, forming clusters of elongated lenticular and irregular shape. Patchy segregations of magnetite, zircon, and titanomorphite are confined to biotite accumulations. An interesting feature of the rock is the high content of apatite (up to 5\%).

\section{Geochemistry}

In terms of chemical composition, metavolcanics of the Huliaipole Suite are middle-Mg\# $(35,8-48,7)$ andesites and dacites of the normal potassium-sodium series (Igneous rocks., 1983) (Table 1). On the $\mathrm{SiO}_{2}-\mathrm{K}_{2} \mathrm{O}$ plot, they fall into the fields of high $-\mathrm{K}$ andesites and dacites of the calc-alkaline series. They have high concentrations of $\mathrm{Sr}$ (743-816 ppm) and $\mathrm{Ba}(1400-2116 \mathrm{ppm})$, and moderate content of $\mathrm{Rb}$ (97-103 ppm) (Table 1). The amounts of transition elements, $\mathrm{Ni}$ (15-34 ppm) and $\mathrm{Cr}$ (21-70 ppm), are close to their content in TTGs. Negative anomalies of $\mathrm{Nb}$ and $\mathrm{Ti}$ are prominent on the multi-element plots (Fig. 5). Rare earth elements in metaandesites and metadacites are highly differentiated: $(\mathrm{La} / \mathrm{Yb})_{\mathrm{N}}=21.9-50.9$ (Fig. 6). The sample 89-156 shows a prominent positive $\mathrm{Eu}$ anomaly, $\mathrm{Eu} / \mathrm{Eu}^{*}=$ $=1.26$; the rest of the samples lack positive $\mathrm{Eu}$ anomaly. The high $\mathrm{Th} / \mathrm{Yb}$ ratio (7.4-13.2) and low $\mathrm{Nb} / \mathrm{La}(0.14-0.20)$ indicate crustal contamination (Table 1).

\section{U-Pb geochronology and Lu-Hf isotope composition}

The LA-ICP-MS method was applied to determine the $\mathrm{U}-\mathrm{Pb}$ age and $\mathrm{Hf}$ isotopic composition in zircons from metadacites of the Huliaipole Suite 
Fig. 7. Cathodoluminescence images of the studied zircon crystals from metadacites of the Huliaipole Suite (drill-hole 625-B, depth 424.4-429.4 m, sample 89-388). Numbers of the analyzes and ${ }^{207} \mathrm{~Pb} /{ }^{206} \mathrm{~Pb}$ ages are shown

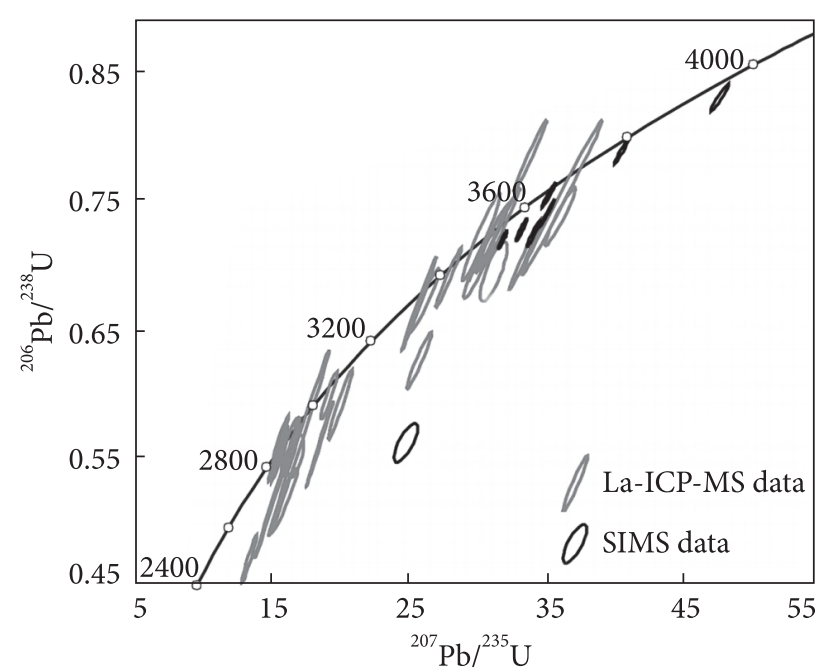

Fig. 8. U-Pb diagram with concordia for zircons from metadacites of the Huliaipole Suite (Drill-hole 625-B, depth 424.4-429.4 meters, sample 89-388)

(Table 2). A total of 34 zircon crystals was analyzed. In two crystals both core and rim parts have been analysed. In one case both core and rim yielded
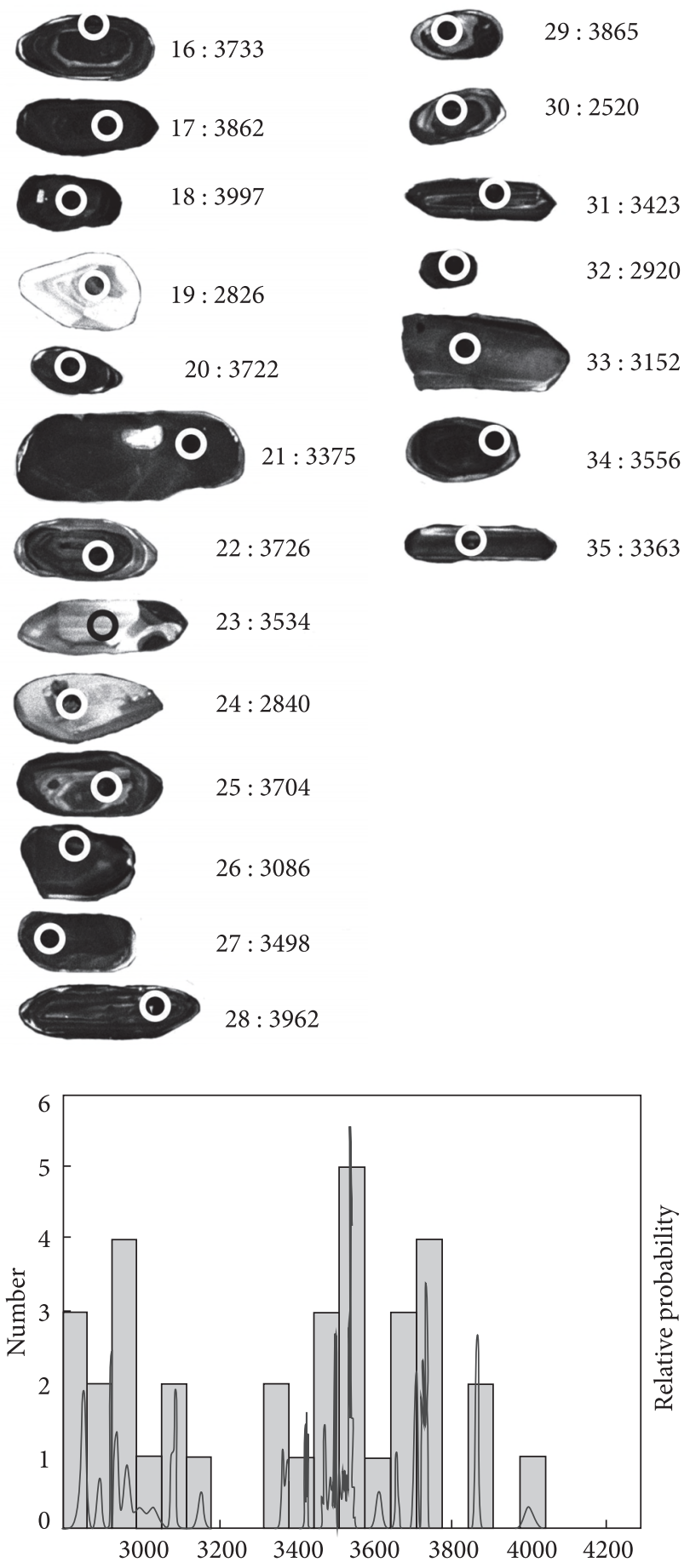

Fig. 9. ${ }^{207} \mathrm{~Pb} /{ }^{206} \mathrm{~Pb}$ age distribution for zircons from metadacites of the Huliaipole Suite (Drill-hole 625-B, depth 424.4-429.4 meters, sample 89-388)

identical within the error results (analyses 5 and 6). However, in the second crystal, the rim yielded the of $3471 \mathrm{Ma}$ which was significantly older than the ${ }^{207} \mathrm{~Pb} /{ }^{206} \mathrm{~Pb}$ age of the core (3029 Ma, analyses 12 and 13$)$. 
The oldest ages, exceeding $3800 \mathrm{Ma}$, have been obtained for the core parts of zircon grains. However, several ages exceeding $3700 \mathrm{Ma}$ have been produced in the rim parts of the crystals (Fig. 7). The age of the most ancient zircons was confirmed by dating with the secondaryion mass spectrometry (SIMS) method (Fig. 8).

According to the obtained data, two main populations of zircon can be distinguished (Fig. 8, 9). The first population embraces zircons with an age in the range of 3085-2850 Ma. The Hf isotopic composition varies within wide limits: 6 crystals have $\varepsilon \mathrm{Hf}$ values from 6.2 to -0.5 ; other 6 have values from -7.5 to -21 (Table 3, Fig. 10). Thus, zircons of this group have been derived from rocks of different genesis: some of them were of juvenile origin, while others were formed due to reworking of an ancient crust. The second population comprises zircons with an age of 3700-3360 Ma, which also have variable $\mathrm{Hf}$ isotope characteristics: from juvenile ( $\varepsilon \mathrm{Hf}$ up to 1.6) and negative $\varepsilon \mathrm{Hf}$ values (down to -7.7 at an age of $3705 \mathrm{Ma}$ ).

Table 2. Results of $\mathbf{U}-\mathbf{P b}$ isotope dating of zircons from metadacites of the Huliaipole Suite arranged in descending

\begin{tabular}{|c|c|c|c|c|c|c|c|c|c|c|}
\hline \multirow{2}{*}{ \# analysis } & \multicolumn{2}{|c|}{ Concentration, ppm } & \multirow{2}{*}{\begin{tabular}{|c} 
Mass ratio \\
$\mathrm{Th} / \mathrm{U}$
\end{tabular}} & \multicolumn{7}{|c|}{ Isotopic ratio } \\
\hline & $\mathrm{U}$ & Th & & ${ }^{207} \mathrm{~Pb} /{ }^{235} \mathrm{U}$ & $2 \sigma$ & ${ }^{206} \mathrm{~Pb} /{ }^{238} \mathrm{U}$ & $2 \sigma$ & Rho & ${ }^{207} \mathrm{~Pb} /{ }^{206} \mathrm{~Pb}$ & $2 \sigma$ \\
\hline 89-388-18 & 176 & 109 & 0.62 & 49.900 & 2.507 & 0.84 & 0.03 & 0.98 & 0.424 & 0.011 \\
\hline $89-388-29$ & 61 & 38 & 0.62 & 42.280 & 1.157 & 0.79 & 0.02 & 0.98 & 0.389 & 0.008 \\
\hline $89-388-17$ & 165 & 96 & 0.58 & 44.000 & 1.409 & 0.81 & 0.02 & 0.97 & 0.388 & 0.008 \\
\hline $89-388-14$ & 148 & 76 & 0.51 & 37.430 & 1.096 & 0.77 & 0.02 & 0.99 & 0.356 & 0.007 \\
\hline $89-388-16$ & 188 & 73 & 0.39 & 37.060 & 0.923 & 0.76 & 0.02 & 0.99 & 0.356 & 0.007 \\
\hline $89-388-22$ & 295 & 74 & 0.25 & 37.080 & 0.980 & 0.75 & 0.02 & 0.98 & 0.354 & 0.007 \\
\hline $89-388-20$ & 171 & 136 & 0.79 & 38.590 & 1.232 & 0.79 & 0.02 & 0.98 & 0.354 & 0.007 \\
\hline $89-388-9$ & 276 & 85 & 0.31 & 36.400 & 2.412 & 0.76 & 0.05 & 0.99 & 0.350 & 0.007 \\
\hline $89-388-25$ & 245 & 15 & 0.06 & 36.250 & 0.910 & 0.74 & 0.02 & 0.96 & 0.349 & 0.007 \\
\hline $89-388-34$ & 490 & 7 & 0.01 & 33.720 & 1.009 & 0.71 & 0.02 & 0.99 & 0.339 & 0.007 \\
\hline $89-388-10$ & 357 & 122 & 0.34 & 31.390 & 0.822 & 0.70 & 0.02 & 0.79 & 0.329 & 0.007 \\
\hline $89-388-6$ & 48 & 16 & 0.33 & 34.070 & 0.984 & 0.79 & 0.02 & 0.99 & 0.314 & 0.006 \\
\hline $89-388-1$ & 70 & 28 & 0.40 & 31.250 & 0.938 & 0.72 & 0.02 & 0.98 & 0.313 & 0.006 \\
\hline $89-388-5$ & 117 & 83 & 0.71 & 31.060 & 0.843 & 0.72 & 0.02 & 0.98 & 0.313 & 0.006 \\
\hline $89-388-23$ & 60 & 23 & 0.38 & 32.040 & 1.009 & 0.74 & 0.02 & 0.99 & 0.313 & 0.006 \\
\hline $89-388-30$ & 234 & 170 & 0.73 & 30.330 & 0.957 & 0.70 & 0.02 & 0.94 & 0.310 & 0.006 \\
\hline 89-388-27 & 209 & 153 & 0.73 & 30.350 & 0.686 & 0.71 & 0.02 & 0.99 & 0.305 & 0.006 \\
\hline 89-388-7 & 167 & 39 & 0.23 & 30.480 & 1.120 & 0.73 & 0.03 & 0.97 & 0.303 & 0.006 \\
\hline 89-388-13 & 624 & 24 & 0.04 & 25.900 & 0.748 & 0.63 & 0.02 & 0.96 & 0.300 & 0.006 \\
\hline $89-388-31$ & 163 & 76 & 0.47 & 28.060 & 0.752 & 0.69 & 0.02 & 0.98 & 0.291 & 0.006 \\
\hline $89-388-21$ & 201 & 79 & 0.39 & 26.330 & 0.876 & 0.68 & 0.02 & 0.96 & 0.282 & 0.006 \\
\hline $89-388-35$ & 68 & 52 & 0.76 & 25.920 & 1.030 & 0.67 & 0.03 & 0.99 & 0.280 & 0.006 \\
\hline $89-388-33$ & 193 & 77 & 0.40 & 20.120 & 0.706 & 0.59 & 0.02 & 0.97 & 0.245 & 0.005 \\
\hline $89-388-26$ & 230 & 244 & 1.07 & 18.620 & 0.820 & 0.56 & 0.03 & 1.00 & 0.235 & 0.005 \\
\hline $89-388-15$ & 187 & 63 & 0.34 & 19.300 & 0.471 & 0.60 & 0.01 & 0.93 & 0.234 & 0.005 \\
\hline $89-388-12$ & 426 & 38 & 0.09 & 16.020 & 0.825 & 0.52 & 0.02 & 0.95 & 0.227 & 0.006 \\
\hline 89-388-3 & 97 & 38 & 0.39 & 16.850 & 0.451 & 0.55 & 0.01 & 0.52 & 0.222 & 0.006 \\
\hline $89-388-28$ & 139 & 32 & 0.23 & 17.100 & 1.832 & 0.56 & 0.06 & 1.00 & 0.218 & 0.005 \\
\hline $89-388-4$ & 129 & 57 & 0.44 & 16.500 & 0.542 & 0.56 & 0.02 & 0.82 & 0.216 & 0.006 \\
\hline 89-388-2 & 258 & 119 & 0.46 & 15.500 & 1.336 & 0.53 & 0.05 & 1.00 & 0.214 & 0.004 \\
\hline $89-388-32$ & 512 & 441 & 0.86 & 16.590 & 0.520 & 0.56 & 0.02 & 1.00 & 0.212 & 0.004 \\
\hline 89-388-11 & 105 & 5 & 0.05 & 13.470 & 0.450 & 0.47 & 0.02 & 0.97 & 0.208 & 0.004 \\
\hline $89-388-8$ & 63 & 81 & 1.28 & 15.610 & 0.615 & 0.56 & 0.02 & 0.99 & 0.203 & 0.004 \\
\hline 89-388-19 & 46 & 71 & 1.54 & 15.680 & 0.485 & 0.55 & 0.02 & 0.98 & 0.203 & 0.004 \\
\hline $89-388-24$ & 39 & 41 & 1.05 & 15.720 & 0.414 & 0.56 & 0.01 & 0.94 & 0.202 & 0.004 \\
\hline
\end{tabular}


Two zircon crystals with the age exceeding $3800 \mathrm{Ma}$ have been found ( $3805 \mathrm{Ma}$ with $\varepsilon \mathrm{Hf}=$ $=-3.3$, and $3971 \mathrm{Ma}$ with $\varepsilon \mathrm{Hf}=-1.3$ ). These zircons are the oldest ones so far found in the Ukrainian Shield. Their isotopic characteristics indicate the presence of Hadean material within the Azov Domain of the Ukrainian Shield. The minimum model age for the crystallization of this material, calculated at $\mathrm{Lu} / \mathrm{Hf}=0$ for zircons with the lowest $\varepsilon H f$ values in each age population, is about $4.1 \mathrm{Ga}$ (Fig. 10).

\section{Discussion}

Two main zircon populations found in metavolcanics of the Huliaipole Suite resemble in terms of their $\mathrm{U}-\mathrm{Pb}$ and $\mathrm{Hf}$ isotope systematics zircons from the Archean metasedimentary rocks of the Soroki Greenstone Belt of the Azov Domain (Claesson et al., 2015), and quartzites of the Bouh Series of the Dniester-Bouh Domain of the Ukrainian Shield (Shumlyanskyy, 2012a; Shumlyanskyy et al., 2015). At the same time, the older

order of ${ }^{207} \mathrm{~Pb} /{ }^{206} \mathrm{~Pb}$ ages (Drill-hole 625-B, depth 424.4-429.4 meters, sample 89-388)

\begin{tabular}{|c|c|c|c|c|c|c|c|c|c|c|}
\hline \multirow[b]{2}{*}{${ }^{208} \mathrm{~Pb} /{ }^{232} \mathrm{Th}$} & \multirow[b]{2}{*}{$2 \sigma$} & \multicolumn{8}{|c|}{ Isotopic age, $\mathrm{Ma}$} & \multirow{2}{*}{$\begin{array}{c}\text { Mass ratio } \\
\text { Discordance, \% }\end{array}$} \\
\hline & & ${ }^{207} \mathrm{~Pb} /{ }^{235} \mathrm{U}$ & $2 \sigma$ & ${ }^{206} \mathrm{~Pb} /{ }^{238} \mathrm{U}$ & $2 \sigma$ & ${ }^{208} \mathrm{~Pb} /{ }^{232} \mathrm{Th}$ & $2 \sigma$ & ${ }^{207} \mathrm{~Pb} /{ }^{206} \mathrm{~Pb}$ & $2 \sigma$ & \\
\hline 0.213 & 0.006 & 3986 & 49 & 3940 & 100 & 3897 & 78 & 3997 & 25 & 2.2 \\
\hline 0.198 & 0.006 & 3831 & 20 & 3739 & 59 & 3644 & 84 & 3865 & 4 & 3.4 \\
\hline 0.211 & 0.006 & 3863 & 25 & 3832 & 66 & 3866 & 81 & 3862 & 7 & 1.8 \\
\hline 0.212 & 0.007 & 3704 & 21 & 3662 & 56 & 3888 & 92 & 3734 & 5 & 2.1 \\
\hline 0.215 & 0.005 & 3695 & 15 & 3637 & 36 & 3940 & 50 & 3733 & 4 & 2.6 \\
\hline 0.192 & 0.006 & 3695 & 17 & 3609 & 47 & 3551 & 72 & 3726 & 4 & 3.3 \\
\hline 0.209 & 0.006 & 3740 & 22 & 3748 & 58 & 3831 & 79 & 3722 & 5 & 0.8 \\
\hline 0.217 & 0.019 & 3667 & 62 & 3620 & 170 & 4050 & 340 & 3705 & 9 & 2.3 \\
\hline 0.229 & 0.011 & 3677 & 17 & 3575 & 43 & 4160 & 170 & 3704 & 6 & 3.8 \\
\hline 0.169 & 0.014 & 3601 & 22 & 3464 & 66 & 3150 & 240 & 3656 & 7 & 4.8 \\
\hline 0.209 & 0.010 & 3531 & 17 & 3411 & 50 & 3830 & 150 & 3611 & 15 & 4.4 \\
\hline 0.218 & 0.008 & 3611 & 21 & 3749 & 59 & 3980 & 120 & 3539 & 8 & -2.8 \\
\hline 0.197 & 0.008 & 3526 & 22 & 3510 & 62 & 3630 & 110 & 3538 & 6 & 1.5 \\
\hline 0.201 & 0.006 & 3520 & 18 & 3501 & 48 & 3707 & 65 & 3537 & 3 & 1.5 \\
\hline 0.188 & 0.008 & 3551 & 24 & 3551 & 66 & 3490 & 130 & 3534 & 7 & 1.0 \\
\hline 0.187 & 0.005 & 3496 & 24 & 3432 & 62 & 3471 & 65 & 3520 & 10 & 2.8 \\
\hline 0.185 & 0.004 & 3498 & 10 & 3462 & 33 & 3436 & 33 & 3498 & 3 & 2.0 \\
\hline 0.198 & 0.006 & 3500 & 30 & 3513 & 88 & 3654 & 71 & 3486 & 11 & 0.6 \\
\hline 0.197 & 0.007 & 3342 & 20 & 3141 & 53 & 3635 & 89 & 3471 & 5 & 7.0 \\
\hline 0.183 & 0.005 & 3421 & 18 & 3394 & 51 & 3395 & 59 & 3423 & 5 & 1.8 \\
\hline 0.177 & 0.005 & 3358 & 27 & 3323 & 57 & 3298 & 67 & 3375 & 8 & 2.0 \\
\hline 0.182 & 0.009 & 3341 & 34 & 3310 & 100 & 3370 & 150 & 3363 & 7 & 1.9 \\
\hline 0.159 & 0.004 & 3096 & 29 & 2999 & 77 & 2976 & 50 & 3152 & 15 & 4.1 \\
\hline 0.119 & 0.023 & 3019 & 39 & 2902 & 95 & 2250 & 420 & 3086 & 4 & 4.9 \\
\hline 0.182 & 0.005 & 3056 & 14 & 3031 & 35 & 3371 & 64 & 3078 & 7 & 1.8 \\
\hline 0.153 & 0.006 & 2885 & 43 & 2712 & 64 & 2884 & 99 & 3029 & 26 & 7.0 \\
\hline 0.206 & 0.010 & 2926 & 17 & 2837 & 33 & 3790 & 150 & 2993 & 27 & 4.0 \\
\hline 0.166 & 0.013 & 2920 & 110 & 2860 & 240 & 3100 & 220 & 2962 & 12 & 3.1 \\
\hline 0.121 & 0.005 & 2905 & 25 & 2864 & 60 & 2308 & 78 & 2953 & 28 & 2.4 \\
\hline 0.060 & 0.009 & 2838 & 72 & 2720 & 180 & 1170 & 170 & 2936 & 6 & 5.2 \\
\hline 0.153 & 0.005 & 2910 & 24 & 2875 & 58 & 2879 & 75 & 2920 & 3 & 2.2 \\
\hline 0.067 & 0.013 & 2712 & 26 & 2511 & 41 & 1320 & 250 & 2892 & 11 & 8.4 \\
\hline 0.163 & 0.006 & 2851 & 33 & 2860 & 76 & 3058 & 79 & 2848 & 7 & 0.7 \\
\hline 0.150 & 0.004 & 2856 & 23 & 2839 & 52 & 2826 & 58 & 2852 & 9 & 1.6 \\
\hline 0.152 & 0.004 & 2860 & 16 & 2878 & 38 & 2864 & 44 & 2840 & 13 & 0.4 \\
\hline
\end{tabular}




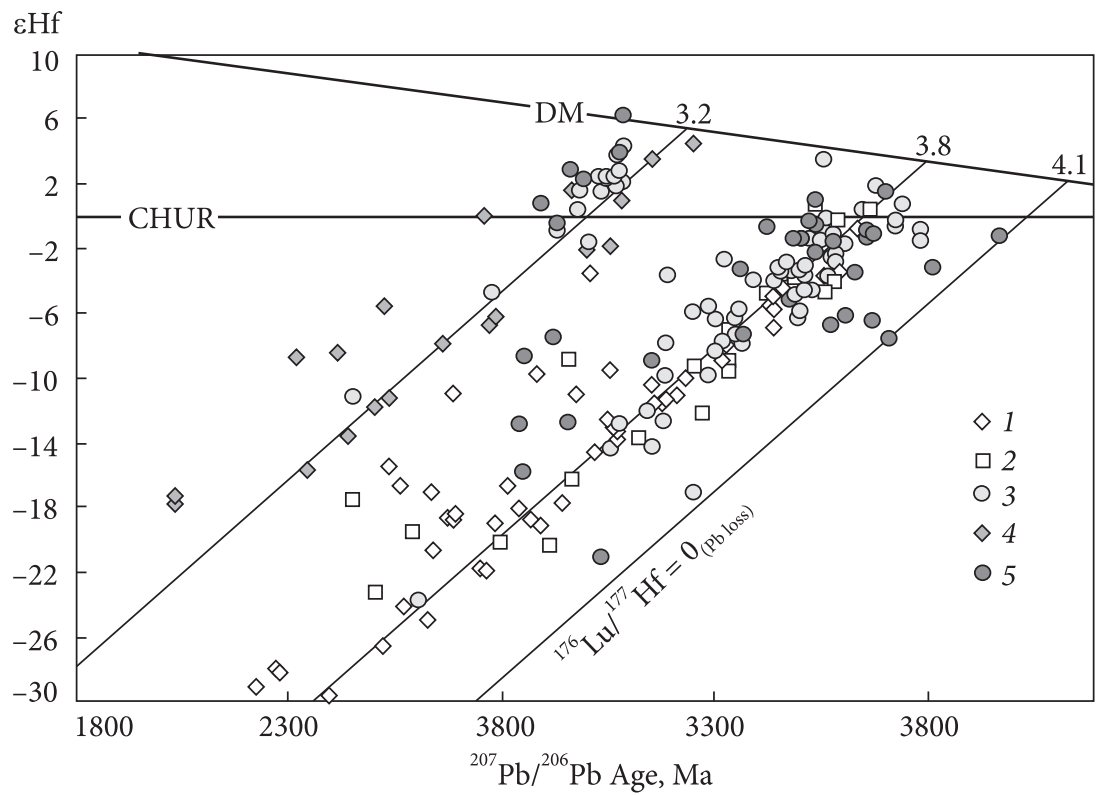

Fig. 10. Hf isotope systematics of zircons from metadacites of the Huliaipole Syncline. Zircons from other rock complexes of the Ukrainian Shield are shown for comparison. 1 - eoarchaean enderbite of the Dniester-Bouh Series (Claesson et al., 2015); 2 - mafic granulite of the Dniester-Bouh Series (LobachZhuchenko et al., 2016); 3 - archaean metasediments of the Azov Domain (Bibikova et al., 2013); 4 bouh Series quartzite (Shumlyanskyy et al., 2015); 5 - metavolcanics of the Huliaypole Suite

Table 3. Results of Hf isotope study of zircons from metadacites of the Huliaipole Suite (Drill-hole 625-B, depth 424.4-429.4 meters, sample 89-388)

\begin{tabular}{|c|c|c|c|c|c|c|c|c|c|c|c|}
\hline Spot & $\begin{array}{c}{ }^{207} \mathrm{~Pb} /{ }^{206} \mathrm{~Pb} \\
\text { age, } \mathrm{Ma}\end{array}$ & ${ }^{176} \mathrm{Lu} /{ }^{177} \mathrm{Hf}$ & ${ }^{176} \mathrm{Yb} /{ }^{177} \mathrm{Hf}$ & ${ }^{176} \mathrm{Hf} /{ }^{177} \mathrm{Hf}$ & $\pm 1 \mathrm{~s}$ & ${ }^{176} \mathrm{Hf} /{ }^{177} \mathrm{Hf}_{\mathrm{T}}$ & $\mathrm{eHf}_{\mathrm{T}}$ & $\pm 2 \mathrm{~s}$ & $\begin{array}{c}\mathrm{T}(\mathrm{DM}) \\
\mathrm{Ma}\end{array}$ & $\begin{array}{c}\mathrm{T}(\mathrm{DM})_{\text {felsic, }}^{\mathrm{c}} \\
\mathrm{Ma}\end{array}$ & $\begin{array}{c}\mathrm{T}(\mathrm{DM})^{\mathrm{c}}{ }_{\text {mafic, }} \\
\mathrm{Ma}\end{array}$ \\
\hline 1 & 3538 & 0.000459 & 0.015200 & 0.280460 & 0.000022 & 0.280429 & -2.2 & 1.5 & 3801 & 3913 & 4185 \\
\hline 2 & 2936 & 0.000596 & 0.021500 & 0.280912 & 0.000015 & 0.280878 & -0.5 & 1.0 & 3214 & 3327 & 3611 \\
\hline 3 & 2993 & 0.000313 & 0.010570 & 0.280934 & 0.000023 & 0.280916 & 2.2 & 1.6 & 3162 & 3232 & 3407 \\
\hline 4 & 2953 & 0.001262 & 0.047000 & 0.280591 & 0.000019 & 0.280519 & -12.9 & 1.4 & 3704 & 3988 & 4733 \\
\hline 5 & 3537 & 0.001653 & 0.065200 & 0.280591 & 0.000029 & 0.280478 & -0.5 & 2.0 & 3742 & 3820 & 4027 \\
\hline 6 & 3539 & 0.001384 & 0.050200 & 0.280609 & 0.000019 & 0.280514 & 0.9 & 1.4 & 3691 & 3751 & 3905 \\
\hline 7 & 3486 & 0.001236 & 0.045700 & 0.280568 & 0.000017 & 0.280485 & -1.4 & 1.2 & 3732 & 3830 & 4080 \\
\hline 8 & 2848 & 0.000489 & 0.018410 & 0.280529 & 0.000017 & 0.280502 & -15.9 & 1.2 & 3713 & 4061 & 4932 \\
\hline 9 & 3705 & 0.000803 & 0.028720 & 0.280481 & 0.000022 & 0.280423 & 1.6 & 1.6 & 3806 & 3849 & 3954 \\
\hline 10 & 3611 & 0.000896 & 0.032600 & 0.280327 & 0.000019 & 0.280264 & -6.3 & 1.3 & 4020 & 4188 & 4606 \\
\hline 11 & 2892 & 0.000366 & 0.013140 & 0.280963 & 0.000015 & 0.280943 & 0.8 & 1.0 & 3128 & 3225 & 3467 \\
\hline 12 & 3029 & 0.001140 & 0.042600 & 0.280301 & 0.000022 & 0.280235 & -21.2 & 1.6 & 4080 & 4483 & 5522 \\
\hline 13 & 3471 & 0.001016 & 0.035600 & 0.280459 & 0.000020 & 0.280391 & -5.2 & 1.4 & 3857 & 4012 & 4405 \\
\hline 14 & 3658 & 0.000912 & 0.032600 & 0.280440 & 0.000023 & 0.280375 & -1.2 & 1.6 & 3872 & 3960 & 4180 \\
\hline 15 & 3078 & 0.000699 & 0.023900 & 0.280946 & 0.000023 & 0.280905 & 3.8 & 1.6 & 3177 & 3217 & 3319 \\
\hline 16 & 3682 & 0.000983 & 0.036800 & 0.280433 & 0.000019 & 0.280363 & -1.1 & 1.4 & 3888 & 3972 & 4183 \\
\hline 17 & 3805 & 0.001652 & 0.063100 & 0.280341 & 0.000021 & 0.280219 & -3.3 & 1.5 & 4081 & 4188 & 4466 \\
\hline 18 & 3971 & 0.001608 & 0.063780 & 0.280287 & 0.000023 & 0.280163 & -1.3 & 1.6 & 4149 & 4219 & 4400 \\
\hline 19 & 2852 & 0.001137 & 0.042850 & 0.280766 & 0.000022 & 0.280704 & -8.7 & 1.5 & 3457 & 3687 & 4290 \\
\hline 20 & 3626 & 0.000507 & 0.018830 & 0.280368 & 0.000017 & 0.280332 & -3.5 & 1.2 & 3926 & 4054 & 4365 \\
\hline 21 & 3375 & 0.000883 & 0.029840 & 0.280451 & 0.000018 & 0.280393 & -7.4 & 1.3 & 3854 & 4048 & 4536 \\
\hline 22 & 3576 & 0.001103 & 0.039860 & 0.280497 & 0.000022 & 0.280421 & -1.6 & 1.6 & 3815 & 3911 & 4155 \\
\hline 23 & 3534 & 0.000670 & 0.023100 & 0.280504 & 0.000018 & 0.280458 & -1.2 & 1.3 & 3763 & 3859 & 4095 \\
\hline 24 & 2840 & 0.000375 & 0.012860 & 0.280614 & 0.000020 & 0.280594 & -12.9 & 1.4 & 3590 & 3896 & 4656 \\
\hline 25 & 3704 & 0.000986 & 0.038100 & 0.280234 & 0.000020 & 0.280163 & -7.7 & 1.4 & 4153 & 4336 & 4794 \\
\hline 26 & 3086 & 0.001012 & 0.036830 & 0.281026 & 0.000017 & 0.280966 & 6.2 & 1.2 & 3095 & 3099 & 3108 \\
\hline 27 & 3498 & 0.000838 & 0.032050 & 0.280536 & 0.000021 & 0.280479 & -1.4 & 1.5 & 3737 & 3835 & 4080 \\
\hline 28 & 2962 & 0.001820 & 0.071000 & 0.281057 & 0.000025 & 0.280953 & 2.8 & 1.8 & 3119 & 3175 & 3330 \\
\hline
\end{tabular}


The End of Table 3

\begin{tabular}{|l|c|c|c|c|c|c|c|c|c|c|c|}
\hline Spot & $\begin{array}{c}{ }^{207} \mathrm{~Pb} /{ }^{206} \mathrm{~Pb} \\
\mathrm{age}, \mathrm{Ma}\end{array}$ & ${ }^{176} \mathrm{Lu} /{ }^{177} \mathrm{Hf}$ & ${ }^{176} \mathrm{Yb} /{ }^{177} \mathrm{Hf}$ & ${ }^{176} \mathrm{Hf} /{ }^{177} \mathrm{Hf}$ & $\pm 1 \mathrm{~s}$ & ${ }^{176} \mathrm{Hf} /{ }^{177} \mathrm{Hf}_{\mathrm{T}}$ & $\mathrm{eHf}_{\mathrm{T}}$ & $\pm 2 \mathrm{~s}$ & $\begin{array}{c}\mathrm{T}(\mathrm{DM}), \\
\mathrm{Ma}\end{array}$ & $\begin{array}{c}\mathrm{T}(\mathrm{DM})_{\text {felsic, }}^{\mathrm{T}} \\
\mathrm{Ma}(\mathrm{DM})_{\text {mafic, }}^{\mathrm{c}} \\
\mathrm{Ma}\end{array}$ \\
\hline 29 & 3574 & 0.000850 & 0.030710 & 0.280338 & 0.000025 & 0.280279 & -6.7 & 1.8 & 4001 & 4176 & 4612 \\
30 & 3520 & 0.000580 & 0.019600 & 0.280537 & 0.000019 & 0.280498 & -0.2 & 1.3 & 3711 & 3791 & 3988 \\
32 & 3423 & 0.001443 & 0.055600 & 0.280645 & 0.000020 & 0.280550 & -0.6 & 1.4 & 3648 & 3735 & 3963 \\
33 & 3152 & 0.000923 & 0.034900 & 0.280554 & 0.000022 & 0.280498 & -8.9 & 1.6 & 3721 & 3947 & 4521 \\
34 & 3656 & 0.000795 & 0.027630 & 0.280445 & 0.000020 & 0.280389 & -0.8 & 1.4 & 3853 & 3935 & 4139 \\
35 & 3363 & 0.001620 & 0.061500 & 0.280619 & 0.000023 & 0.280514 & -3.3 & 1.7 & 3701 & 3828 & 4166 \\
\hline
\end{tabular}

(3700-3360 Ma) zircon population reveal similarity to zircons from the Eoarchean enderbites of the Dniester-Bouh Domain (Claesson et al., 2015; Shumlyanskyy, 2012b; Shumlyanskyy et al., 2021). One of the zircon crystals found in the metasedimentary rocks of the Soroki Greenstone Belt (Claesson et al., 2015) resembles the oldest zircon crystals from the metavolcanic rocks of the Huliaipole Suite and has a minimum hafnium model age of ca. $4.1 \mathrm{Ga}$.

Another intriguing observation is that similarly to the iron-bearing metasedimentary successions of the Middle Dnieper Domain, no zircons younger than ca. $2800 \mathrm{Ma}$ were found either in the greenstone belts of the Azov Domain or the metavolcanics of the Huliaipole Suite (e.g., Bibikova et al., 2010; Bobrov et al., 2011; Stepanyuk et al., 2020; Artemenko et al., 2020), supporting a common geological history of these two domains in the Neoarchean and Paleoproterozoic.

The high $\mathrm{Th} / \mathrm{Yb}$ (7.4-13.2) and low $\mathrm{Nb} / \mathrm{La}$ (0.140.20 ) ratios in the metavolcanics of the Huliaipole Suite and the presence of the old inherited from the source rocks zircons reaching in age almost $4.0 \mathrm{Ga}$ can be explained by predominantly crustal source of the initial melts. There is a group of crystals that have Hadean 'felsic crust' model ages calculated using average continental crust ${ }^{176} \mathrm{Lu} /{ }^{177} \mathrm{Hf}$ value of 0.015 (Griffin et al., 2004), and 'mafic crust' model ages calculated using ${ }^{176} \mathrm{Lu} /{ }^{177} \mathrm{Hf}$ value of 0.021 (Kemp et al., 2006; Table 4). Such crystals provide strong evidence of the presence of Hadean material in the Azov Domain. However, six crystals belonging to the young popu- lation have $\varepsilon \mathrm{Hf}$ values characteristic to chondritic to depleted mantle sources, indicating significant input of the juvenile mantle material into the source of metavolcanic rocks of the Huliaipole Suite.

The obtained data have shown that the Huliaipole block, despite its relatively small size $(30 \times 50 \mathrm{~km})$ hosts mineral and rock relicts belonging to the Eoarchean, Paleoarchean, and Mesoarchean eras (ca. 4000-2900 Ma), that indicates prolonged evolution of the Archean crust, probably within the single nucleoid structure. The unique peculiarity of this structure is that it has never experienced granulite stage metamorphism. This allows consideration of the Huliaipole block as an example of the continental crust that has been formed in a plume geodynamic regime.

\section{Conclusions}

The Huliaipole Block of the Azov Domain of the Ukrainian Shield carries evidence for a protracted geological evolution from the Hadean to the Palaeoproterozoic. The Azov Domain indicates the existence of the cratonic nucleus formed from 3.97 to $3.3 \mathrm{Ga}$ ago. In the Mesoarchean (3.2$3.0 \mathrm{Ga}$ ), the Huliaipole Block was a part of the Middle-Dnieper-Azov-Kursk granite-greenstone craton. Felsic and intermediate volcanic rocks of the Huliaipole Suite could have formed due to melting of the sialic continental crust, including components of the Hadean and Archean age, as a result of underplating by mafic magmas during the formation of Neoarchean-Paleoproterozoic extension-related rift structures. 
REFERENCES

Artemenko G.V., Demedyuk V.V., Bartnitskiy E.N., Dovbush T.I., Shpylchak V.A, 2002. 3400 Ma is the minimum age of tonalites of the Vasilkovka area of the Orekhov-Pavlograd zone. Geological Journal (Ukraine), No. 2 (300), pp. 8895 (in Russian).

Artemenko G.V., Shumlyanskyy L.V., Wilde S.A., 2020. The lower age boundary of the formation of metaterrigenous rocks of the Vysokopillya greenstone structure (the Middle-Dnieper Domain of the Ukrainian Shield). Geological Journal (Ukraine) No. 2 (371), pp. 3-17 (in Russian).

Artemenko G.V., Shumlyanskyy L.V., Shvaika I.A., 2014. Late Paleoarchean tonalite gneisses of the West Azov block (the Azov Domain of the Ukrainian shield). Geological Journal (Ukraine), No. 4 (349), pp. 91-102 (in Russian).

Berzenin B.Z., 1990. The study of the composition, ore-bearing and correlation of the sections of the Osipenko, Huliaipole, Sachki and Kosivtseve strata of the Azov Block of the Ukrainian Shield. Novomoskovsk GEE, "Yuzhukrgeologiya". Dnepropetrovsk (in Russian).

Bibikova E.V., Claesson S., Fedotova A.A., Artemenko G.V., Ilyinsky L., 2010. Terrigenous zircon of the Archean greenstone belts - a source of information about the early crust of the Earth: Azov and Dnieper regions, Ukrainian Shield. Geokhimiya, No. 9, pp. 899-916 (in Russian).

Bibikova E.V., Claesson S., Fedotova A.A., Stepanyuk L.M., Shumlyanskyy L.V., Kirnozova T.I., Fugzan M.M., Ilinsky L.S., 2013. Isotope geochronological (U-Th-Pb, Lu-Hf) study of zircons from the Archean magmatic and metasedimentary rocks of the Podolia Domain, Ukrainian shield. Geochemistry International, No. 51, pp. 87-108).

Bibikova E.V., Williams I.S., 1990. Ion microprobe U-Th-Pb isotopic studies of zircons from three Early Precambrian areas in the USSR. Precambr. Res., No. 4, pp. 203-221.

Bobrov O.B., Stepanyuk L.M., Paran 'ko I.S., Ponomarenko O.M., Shumlyanskyy L.V., Dhuime B., 2011. Genesis and age of zircon from the "Lativka" horizon of the Kryvyi Rih Series of the Ukrainian Shield. Mineralohichnyy Zhurnal, 2011, vol. 33, No. 1, pp. 30-40 (in Ukrainian).

Bouvier, A., Vervoort, J.D., Patchett, P.J., 2008. The Lu-Hf and Sm-Nd isotopic composition of CHUR: constraints from unequilibrated chondrites and implications for the bulk composition of terrestrial planets. Earth Planet. Sci. Lett., No. 273, pp. 48-57 (in English).

Chu, N.-C., Taylor, R.N., Chavagnac, V., Nesbitt, R.W., Boella, R.M., Milton, J.A., German, C.R., Bayon, G., Burton, K., 2002. Hf isotope ratio analysis using multi-collector inductively coupled plasma mass spectrometry: an evaluation of isobaric interference corrections. J. Anal. At. Spectrom., No. 17, pp. 1567-1574.

Claesson S., Bibikova E., Shumlyanskyy L., Dhuime B., Hawkesworth C., 2015. The oldest crust in the Ukrainian Shield - Eoarchean $\mathrm{U}-\mathrm{Pb}$ ages and Hf-Nd constraints from enderbites and metasediments In: Van Kranendonk, N.M.W., Parman, S., Shirey, S., Clift, P.D. (Eds.), Continent Formation Through Time. Geological Society, London, Special Publications, No. 389, pp. 227-259.

Claesson S., Artemenko G., Bogdanova S., Shumlyanskyy L., 2019. Archean crustal evolution in the Ukrainian shield. In: Earth's oldest rocks, second edition. Eds: Martin J. van Kranendonk, Vickie Bennett, Elis Hoffmann, Elsevier, pp. 837854.

Geological map of the pre-Mesozoic rocks on the territory of the KP Pivdenukrgeologiya. M: 1:500 000, 2014. Compiled by Pereversev S.I. (in Ukrainian).

Glevasskiy E.B., Bosaya N.I., Polunovskiy R.M., 1985. The Huliaipole Suite. In; Stratigraphic sections of the Precambrian of the Ukrainian Shield. Kyiv: Naukova Dumka, pp. 137-142 (in Russian).

Griffin, W.L., Belousova, E.A., Shee, S.R., Pearson, N.J., O’Reilly, S.Y., 2004. Archean crustal evolution in the northern Yilgarn Craton: U-Pb and Hf-isotope evidence from detrital zircons. Precambr. Res., vol. 131, pp. 231-282.

Igneous rocks: Classification, nomenclature, petrography Ed. O A. Bogatikov, V.I. Gonshakova et al., 1983. Moscow: Nauka, vol. 1, pt. 1, 365 p. (in Russian).

Jackson S.E., Pearson N.J., Griffin W.L., Belousova E.A., 2004. The application of laser ablation-inductively coupled plasma-mass spectrometry to in situ U-Pb zircon geochronology. Chem. Geol., vol. 211, pp. 47-69.

Kemp, A.I.S., Hawkesworth, C.J., Paterson, B.A., Kinny, P.D., 2006. Episodic growth of the Gondwana supercontinent from hafnium and oxygen isotopes in zircon. Nature, vol. 439, pp. 580-583.

Kylander-Clark A.R.C., Hacker B.R., Cottle J.M., 2013. Laser-ablation split-stream ICP petrochronology. Chem. Geol., vol. 345, pp. 99-112.

Lobach-Zhuchenko S.B., Bibikova E.V., Balagansky V.A., Sergeev S.A., Artemenko G.V., Arestova N.A., Shcherbak N.P., Presnyakov S.L., 2010. Paleoarchean tonalites in the Paleoproterozoic Orekhovo-Pavlograd collision zone of the Ukrainian Shield. Reports of RAS, vol. 433, No. 2, pp. 212-218 (in Russian).

Lobach-Zhuchenko S.B., Kaulina A.T., Baltybaev S.K., Balaganskii V.V., Egorova Yu.S., Lokhov K.I., Skublov S.G., Sukach V.V., Bogomolov E.S., Stepanyuk L.M., Galankina O.L., Berezhnaya N.G., Kapitonov I.N., Antonova A.V., Sergeev S.A., 2016. The long (3.7-2.1 Ga) and multistage evolution of the Bug granulite gneiss complex, Ukrainian shield, based on the SIMS U-Pb ages and geochemistry of zircons from a single sample. In: Halla, J., Whitehouse, M.J., Ahmad, T., Bagai, Z. (Eds.), CrusteMantle Interactions and Granitoid Diversification: Insights from Archaean Cratons. Geological Society of London. https://doi.org/10.1144/SP449.3. Special Publications, 449. 
Nozhkin A.D., Krestin E.M., 1984. Radioactive elements in the rocks of the Early Precambrian (at the example of KMA). Moscow: Nauka (in Russian).

Patchett, P., Tatsumoto, M., 1980. Lu-Hf total-rock isochron for the eucrite meteorites. Nature, vol. 288 , pp. 571.

Shcherbak N.P., Artemenko G.V., Bartnitsky E.N., Shpylchak V.A., 2000. The age of granitoids of the Huliaipole block. Reports of the National Academy of Sciences of Ukraine, No. 5, pp. 139-144 (in Russian).

Shumlyanskyy L.V., 2012a. The age and Hf isotope composition of zircons from quartzites of the Middle Bouh area of the Ukrainian Shield. Geokhimiya i rudoutvorennia, vol. 31-32, pp. 136-143 (in Ukrainian).

Shumlyanskyy L.V., 2012b. Geochemistry of pyroxene plagiogneisses (enderbites) of the Bouh area and Hf isotope composition in zircons. Mineralohichnyy Zhurnal, vol. 34, No. 2, pp. 64-79 (in Ukrainian).

Shumlyanskyy L., Hawkesworth C., Dhuime B., Billström K., Claesson S., Storey C., 2015. ${ }^{207} \mathrm{~Pb} /{ }^{206} \mathrm{~Pb}$ ages and Hf isotope composition of zircons from sedimentary rocks of the Ukrainian shield: crustal growth of the south-western part of East European craton from Archaean to Neoproterozoic. Precambr. Res., vol. 260, pp. 39-54.

Shumlyanskyy, L., Wilde, S.A., Nemchin, A.A., Claesson, S., Billström, K., Bagiński, B., 2021. Eoarchean rock association in the Dniester-Bouh Domain of the Ukrainian shield: a suite of LILE-depleted enderbites and mafic granulites. Precambr. Res., 106001.

Sláma, J., Košler, J., Condon, D.J., Crowley, J.L., Gerdes, A., Hanchar, J.M., Horstwood, M.S., Morris, G.A., Nasdala, L., Norberg, N., 2008. Plešovice zircon - a new natural reference material for U-Pb and Hf isotopic microanalysis. Chem. Geol., vol. 249, pp. 1-35.

Söderlund, U., Patchett, J.P., Vervoort, J.D., Isachsen, C.E., 2004. The ${ }^{176} \mathrm{Lu}$ decay constant determined by Lu-Hf and U-Pb isotope systematics of Precambrian mafic intrusions. Earth Planet. Sci. Lett., vol. 219, pp. 311-324.

Stepanyuk L.M., Bobrov O.B., Shpilchak V.O., Stefanishin O.B., Sergov S.A., Lepukhina O.M., 2007. New data on the radiological age of granitoids of the Dobropillya massif (the West Azov area). Article 3. Results of the radiological dating. Collection of scientific work of UkrDGRI, pp. 83-89 (in Ukrainian).

Stepanyuk L.M., Shumlyanskyy L.V., Hoffman A., Hoffman M., Kovalik A., Becker A., 2020. On the Mesoarchean age of detrital zircon from metaterrigenous formations of the Skelyuvatka and Saksagan suites of the Kryviy Rih structure (according to the U-Pb dating). Mineralohichnyy Zhurnal, vol. 42, No. 2, pp. 46-62 (in Ukrainian).

Sun S.S., McDonough W.F., 1989. Chemical and isotopic systematics of oceanic basalts: implications for mantle composition and processes. Saunders A.D., Norry M.J. Magmatism in the Ocean Basins. Geological Society. Special Publication, No. 42, pp. 313-345.

Tatarinova E.A., Artemenko G.V., Dovbush T.I., 2001. The age of detrital and metamorphic zircon in the rocks of the Huliaipole suite. Mineralogicheskiy Zhurnal, vol. 23, No. 2/3, pp. 61-63 (in Russian).

Wiedenbeck M., Alle P., Corfu F., Griffin W.L., Meier M., Oberli F., von Quadt A., Roddick J.C., Spiegel W., 1995. 3 natural zircon standards for U-Th-Pb, Lu-Hf, trace-element and REE analyses. Geostandards Newsletter 19: 1-23.

Zhukov G.V., Andrushchenko I.L., Krivonos V.P., 1978. The Huliaipole area. Ferrous-siliceous formations of the Ukrainian Shield: in 2 vols. Kiev: Naukova Dumka, vol. 1, pp. 299-304 (in Russian).

Received 23.11.2020

Received in revised form 20.01.2020

Accepted 29.01.2021

Г.В. Артеменко ${ }^{1 \star}$, Л.В. Шумлянський ${ }^{1,2}$, S.A. Wilde², M.J. Whitehouse ${ }^{3}$, A.Yu. Bekker ${ }^{4}$

${ }^{1}$ Інститут геохімії, мінералогії та рудоутворення ім. М.П. Семененка НАН України, Київ, Україна

E-mail: regulgeo@gmail.com

2 Університет Кертіна, Школа наук про Землю та планети, Перт, Австралія

E-mail: regulgeo@gmail.com, leonid.shumlyanskyy@curtin.edu.au

${ }^{2}$ Університет Кертіна, Школа наук про Землю та планети, Перт, Австралія

E-mail: S.Wilde@curtin.edu.au

${ }^{3}$ Шведський музей природознавства, Стокгольм, Швеція

E-mail: martin.whitehouse @nrm.se

${ }^{4}$ Відділ наук про Землю та планети, Каліфорнійський університет, Ріверсайд, Каліфорнія, 92521, США

E-mail: andreyb@ucr.edu

* Автор для кореспонденції

U-Pb ВIК ТА Lu-Hf IЗОТОПНА СИСТЕМАТИКА

ЦИРКОНУ 3 МЕТАВУЛКАНІТІВ ГУЛЯЙПІЛЬСЬКОГО БЛОКУ,

ПРИАЗОВСЬКИЙ ДОМЕН УКРАЇНСЬОГО ЩИТА: СВІДЧЕННЯ ПРО ПАЛЕОАРХЕЙ-ГАДЕЙСЬКУ КОРУ

Приазовський район є частиною мезоархейського (3,2-3,0 млрд років) кратону, фрагменти якого збереглися в східній частині «Українського Щита» і на блоці Курської магнітної аномалії. У неоархеї-палеопротерозої він був фрагментований на кілька тектонічних блоків - Вовчанський, Ремівський, Гуляйпільський, Білоцерківський і Салтичанський. Північна частина Гуляйпільського блоку складена тоналіт-тронд’єміт-гранодіоритовою 
асоціацією порід (ТТГ), серед яких знаходиться Косивцівська зеленокам'яна структура. Вона складена метаморфізованими породами джеспіліт-коматиїт-толеїтової асоціації (косивцівська товща), яку співставляють 3 сурською світою конкської серії Середньопридніпровського району. Неоархей-палеопротерозойські утворення представлені осадово-вулканогенними породами гуляйпільської світи і гранітоїдами добропільського і анадольського комплексів. Гранітоїди добропільського комплексу містять велику кількість ксенолітів піроксенітів, гнейсів і плагіогранітоїдів. U-Pb ізотопний вік за цирконом гранітоїдів добропільського комплексу 2040 млн років. Ксеногенний циркон має вік до 3400 млн років. Невеликі інтрузії двопольовошпатових гранітів поширені у Тернуватській структурі. U-Pb вік двопольовошпатових гранітів за монацитом - 2190 млн років. У центральній частині Гуляйпільського блоку розташована Гуляйпільська брахісинкліналь $(3,5 \times 9$ км), яка витягнута в Пн3 напрямку. Ця структура складена осадово-вулканогенними породами гуляйпільської світи, які залягають з неузгодженням на мезоархейських ТТГ. Метавулканіти кислого і середнього складу приурочені, в основному, до залізистих кварцитів середньогуляйпільської підсвіти. В обмеженій кількості вони також зустрічаються в нижньогуляйпольській і верхньогуляйпільській підсвітах. Циркон з метаандезитів і кислих метавулканітів гуляйпільської світи дуже гетерогенний, що вказує на його коровий генезис. Методом LA-ICPMS визначено U-Pb вік популяцій циркону з метадацітов гуляйпільської світи - 3085-2850 і 3700 -3360 млн років. Крім того, виявлено два кристала циркону віком понад 3800 млн років. Згідно 3 геологічними і геохронологічними даними, Гуляйпільський блок, який має розміри $30 \times 50$ км, складений породами і їх реліктами гадейського, архейського і палеопротерозойського еонів. Найдавнішим фундаментом Приазовського мегаблоку є, ймовірно, породи нуклеоїдної структури, яка формувалася від 3,97 до 3,3 млрд років. Унікальною особливістю цієї структури є те, що вона ніколи не зазнавала метаморфізму гранулітової фації. Це дозволяє розглядати Гуляйпільський блок як приклад континентальної кори, яка сформувалася у плюмовому геодинамічному режимі. У мезоархеї (3,2-3,0 млрд років) вона стала частиною Середньопридніпровсько-Приазовсько-Курського граніт-зеленокам'яного терейну. Вулканіти кислого і середнього складу гуляйпільської світи могли утворитися при плавленні порід сіалічної кори, що включала породи гадейського та архейського віку, в результаті андерплейтінга базитових розплавів при формуванні неоархей-палеопротерозойських рифтогенних структур.

Ключові слова: Західне Приазов'я; Гуляйпільський блок; гадей; архей; палеопротерозой; Український щит; $\mathrm{U}-\mathrm{Pb}$ вік. 